\title{
SIMULATION OF THE NORMAL AND EMERGENCY OPERATION OF INTERCONNECTED POWER SYSTEM OF UKRAINE FOR FREQUENCY STABILITY STUDY
}

\author{
O.V. Kyrylenko ${ }^{1}$, V.V. Pavlovsky ${ }^{1}$, A.O. Steliuk ${ }^{1}$, O.V. Lenga ${ }^{1}$, M.V. Vyshnevskyi ${ }^{2}$ \\ 1 - Institute of Electrodynamics, National Academy of Sciences of Ukraine, \\ pr. Peremohy, 56, Kyiv, 03057, Ukraine, \\ 2 - National power company "Ukrenergo", \\ S. Petliury str., 25, Kyiv, 01032, Ukraine.
}

Integration of interconnected power system (IPS) of Ukraine to the European Network Transmission System Operators for Electricity (ENTSO-E) requires an improvement of Ukrainian frequency automatic emergency control and harmonization with load-frequency control according to requirements of ENTSO-E. In order to investigate processes of frequency and active power control, it is necessary to develop the detailed simulation model including models of automatic under frequency load shedding (UFLS) relays, special protection automatics (SPA) of the nuclear power plants, automatic generation control (AGC) as well as 750-220 kV transmission networks of IPS of Ukraine. The frequency stability phenomena have been studied by time domain simulation using the detailed model realized in DIgSILENT PowerFactory software. The simulation results for different disturbances are presented. References 12, figures 5.

Key words: frequency stability, automatic under frequency load shedding, special protection automatics, power flow, primary and secondary control, automatic generation control, interconnected power system.

One of the state priorities of Ukraine is an integration of the national IPS to ENTSO-E grid. Implementing this strategy requires solution of the numerous of tasks. Among others, it's necessary to improve power system dispatch (considering an increasing of the stochastic generating power of the renewables), voltage and reactive power control, power quality etc. The most important task is an improvement of frequency emergency automatics and load-frequency control [1,2]. This paper is devoted to frequency stability simulation in IPS of Ukraine. Performing this study requires a development of the detailed models considering an operation UFLS relays, special frequency protection automatics (SPA), which are used in the islanding schemes of Ukrainian nuclear power plants, and national AGC, and detailed model of 750-220 kV transmission networks. In order to simulate UFLS and AGC operation, a lot of approaches have been utilized [3-10]. In [3], various automatic load shedding strategies are investigated to provide frequency stability in ENTSO-E using simplified system models. In $[4,5]$, the effect of the automatic loading shedding on frequency stability has been analyzed in case of blackout and islanding of the power system. The simulation results are provided by using an example of equivalent model that does not allow to estimate proposed solutions for a real scale power system. In $[9,10]$ load-frequency control is investigated using a model, which is presented by the equivalent elements. In this paper, the detailed model of IPS of Ukraine has been developed including models of UFLS relays, SPA and AGC. Using of the abovementioned model allows to study frequency stability in more detail and with consideration of the loading of interfaces in of IPS of Ukraine. Besides, this advanced software model is capable to be used to simulate these processes in case of wind and solar power plants' participation in frequency control. This is very important toolbox to detail study of frequency stability of IPS of Ukraine with consideration of future integration to ENTSO-e system.

At present time, IPS of Ukraine is divided into five separately operated zones. The main part of the Ukrainian power system operates synchronously with IPS/UPS (Russia, Belarus and Moldova). The maximal demand of this zone is about $23100 \mathrm{MW}$. The second zone is Burshtyn island, operating synchronously with ENTSO-E. It is separated from the main part of the Ukrainian power system. The third zone is presented by small part of the Ukrainian power system in the east, which is energized from Russian unified power system (UPS). The maximal load of this zone is approximately $500 \mathrm{MW}$. The fourth and fifth zones are presented by the island of Luhanska thermal power plant (the fourth zone, its maximal load is about $400 \mathrm{MW}$ ) and the island of Zuyivska/Staribeshivska thermal power plants, which maximum load is $1318 \mathrm{MW}$.

In order to preserve a frequency stability of IPS of Ukraine in case of severe disturbances, UFLS relays are used. Depending on the frequency and operation time settings, there are following categories of UFLS:

(C) Kyrylenko O.V., Pavlovsky V.V., Steliuk A.O., Lenga O.V., Vyshnevskyi M.V., 2017 
1) special UFLS used to prevent a frequency decreasing to operation settings of UFLS-2. Frequency pick-up setting is $49.2 \mathrm{~Hz}$, pick up time is $0.3-0.5 \mathrm{~s}$.

2) protective UFLS, used in order to prevent operation of SPA which isolate of the nuclear plants to island operation in case of a dangerous frequency decreasing (less than $49 \mathrm{~Hz}$ ) in the system. Frequency pick up of this UFLS is $49.1 \mathrm{~Hz}$, pick up time is $0.3-0.5 \mathrm{~s}$.

3) UFLS-1 (the first category) used to prevent a frequency decreasing. This category of high-speed devices UFLS has different frequency setting in order to adapt to various disturbances in IPS of Ukraine (or its isolated parts) and to eliminate a frequency decreasing. Frequency pick up settings are in the range 48,8-47,2 Hz; pick up time $0.3-0.5 \mathrm{~s}$.

4) UFLS- $2 n$ - not combined UFLS-2 (the second category). This is slow category that is not combined with UFLS-1, and must to increase frequency after UFLS-1 picked up when frequency decreases at unacceptably low level. Frequency pick up setting is $49.1 \mathrm{~Hz}$ and time pick up settings are in the range from 5 to $20 \mathrm{sec}$ with intervals $3 \mathrm{sec}$.

5) UFLS-2c - combined UFLS-2 (the second category), which must to eliminate frequency decrease with relatively slow power deficit increase (frequency drift), and to increase the frequency in the case UFLS-2n inefficient operation. Frequency pick up settings are in the range from $48.7 \mathrm{~Hz}$ to 49 $\mathrm{Hz}$; time pick up settings are in the range $21 \mathrm{~s}$ to $60 \mathrm{~s}$.

Besides, in order to ensure the safe operation of nuclear power plants, SPA relays are also used. These devices are configured in such a way, that even short-term reduction of frequency below 46 $\mathrm{Hz}$ was quite avoidance. The SPA operation time with frequency lower than $47 \mathrm{~Hz}$ is less than 10 seconds; lower than $48 \mathrm{~Hz}$ - not exceeding 1 min and lower than $49 \mathrm{~Hz}$ - less than 5 minutes.

The simplified structure of AGC organization in IPS of Ukraine considering its main part is presented in Fig. 1.

In UPS of Russia, the hierarchical structure of AGC is used. The coordinated AGC system of the up-

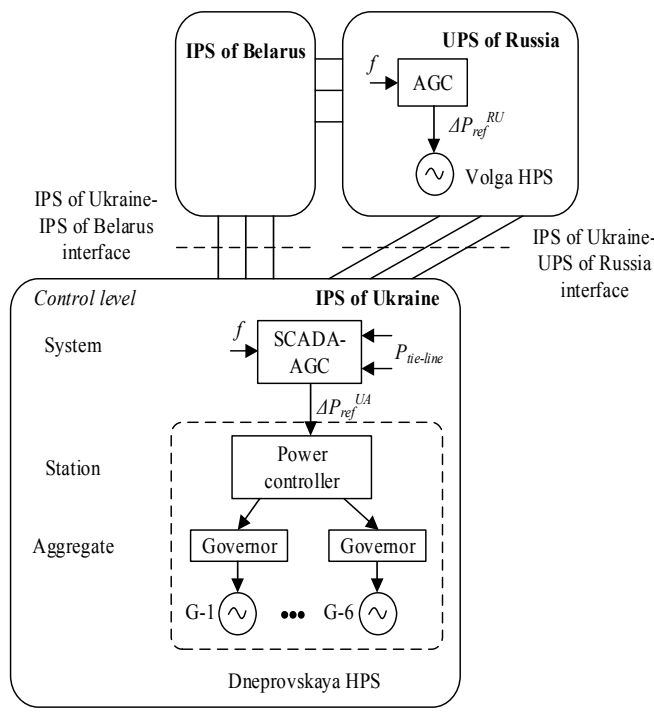

Fig. 1 per level controls the frequency in interconnected power system of Russia with other Commonwealth of Independent States countries by generating a control signal $\Delta P_{r e f R U}$. In European part of Russia, the frequency is controlled by Volga hydroelectric power station (HPS) while in IPS of Belarus the frequency is controlled by dispatcher. In IPS of Ukraine, Dneprovskaya HPS-1 participates in the secondary control only.

The input signals of the national AGC are the frequency in IPS of Ukraine $f$ and tie line interchanges Ptie-line with UPS of Russia and IPS of Belarus. The national AGC regulates the net interchange power and the frequency. Based on these measured signals the proportional integral (PI) controller generates the control signal $\Delta P_{\text {refUA }}$ to the regulating units of Dneprovskaya HPP-1. Further, at power plant control level, this signal is distributed among regulating units of Dneprovskaya HPP-1. At aggregate control level, the turbine governor generates a signal of the turbine power change [11, 12].

Some simulation results for UFLS relay operation in case of two $1000 \mathrm{MW}$ generating units disconnection (isolated operation of IPS of Ukraine) is presented in Fig. 2 and Fig. 3.

As seen in Fig. 3, up to 20 sec. after disturbances a consumption is decreasing due to frequency drop (self-regulation effect). In case of the frequency decreasing to UFLS relay setting, the load is reduced by UFLS operation. The total load reduction is $190 \mathrm{MW}$ at this substation.

Simulation results of AGC operation in case of generating unit disconnection of the ther-

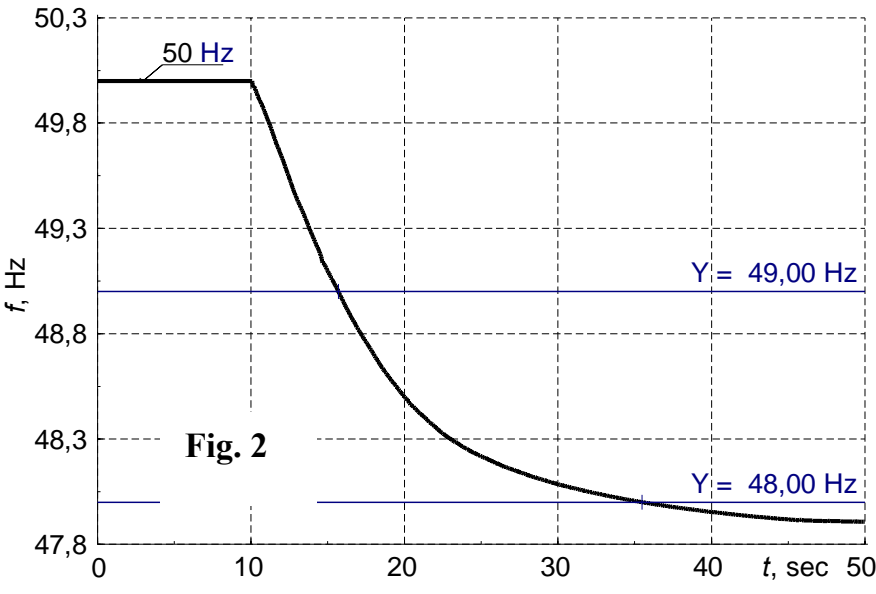


mal power plant (parallel operation of IPS of Ukraine) are presented in Fig. 4-6. The participation factors of

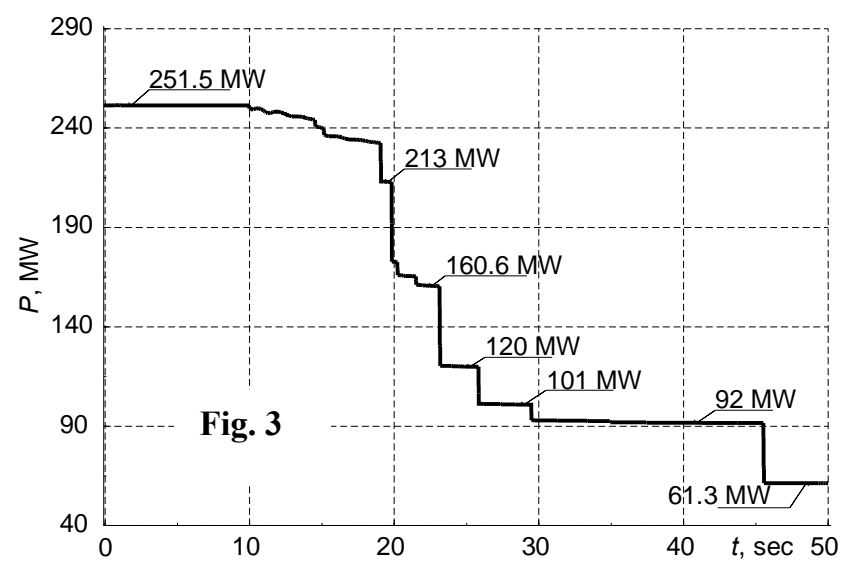
the generating units of Dneprovskaya HPS-1 in the secondary frequency control are equal to $0.2 ; 0.14$; $0.2 ; 0.16 ; 0.18$ and $0.12 \mathrm{pu}$.

As seen in Fig. 4, the generator loss is fully compensated by the power change of the generating units Dneprovskaya HPP-1 according to their participation factors in the secondary frequency control. After secondary frequency control, the net interchange power at the interface between power systems of Ukraine and Russia is also restored at its scheduled value as well (Fig. 5).
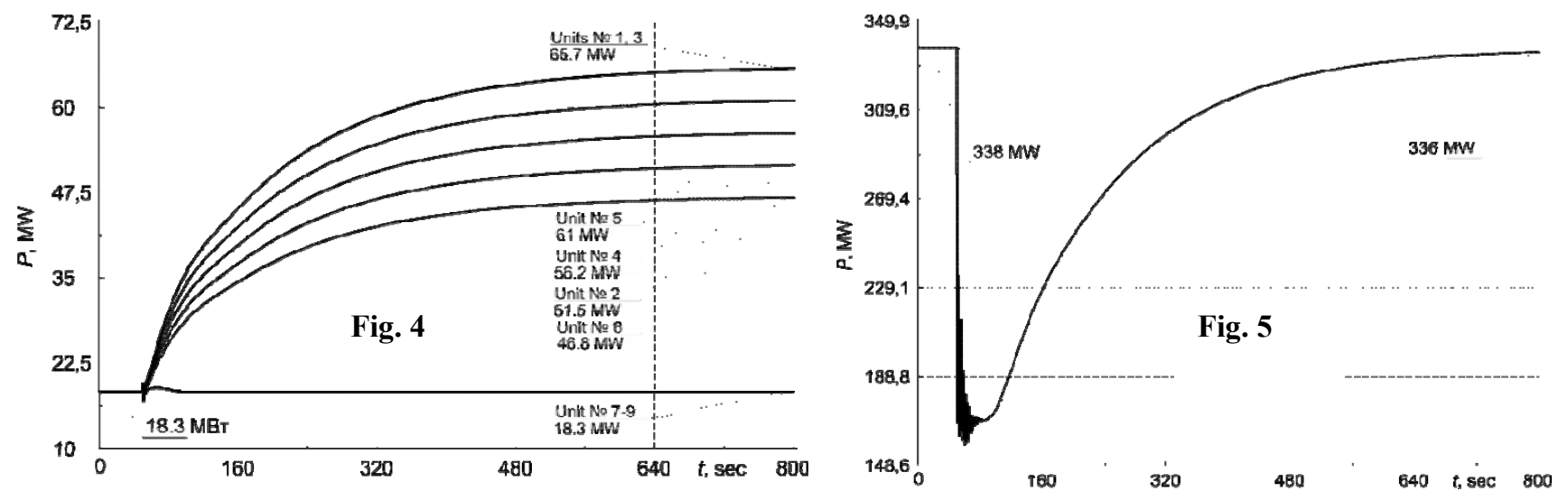

It should be noted, that the simulation of the load-frequency control has been performed considering the normal operation of IPS/UPS. At the same time, identifying of the critical loading of overhead lines in emergency operation of the power system will allow to define these overloadings to prevent their possible disconnection.

The presented simulation results demonstrate an operation of the proposed UFLS, SPA and AGC models of IPS of Ukraine after different disturbances. The developed advances software model is realized in DIgSILENT PowerFactory software.

The model is used to investigate all aspects frequency stability (inertial system response, primary active power control, UFLS and SPA operation, secondary control in IPS of Ukraine) for various scenarios of power imbalances.

1. Alekseev S., Kopylov I., Mashanskii A. Interconnected power utilities description as object of frequency and active power control // Elektrichestvo. - 1980. - No 12. - Pp. 23-30. (Rus)

2. Kyrylenko O., Pavlovsky V., Steliuk A. AGC Software Model Validation for Identification of Renewables Impact on Frequency Control in the IPS of Ukraine / Proceedings of International Conference on Intelligent Energy and Power Systems. - Kyiv, June 2014. - Pp. 141-145.

3. Pavlovsky V., Steliuk A., Lenga O., Zaychenko V., Vyshnevskyi M., Antoniuk Ya. Influence of the frequency and voltage change on load power considering automatic frequency load shedding // Enerhetyka i Elektryfikatsiia. - 2016. - No 4. - Pp. 7-12. (Ukr)

4. Diviya K.C., Nagendra Rao. A novel AGC simulation scheme based on reduced order prime mover models / Conference on Convergent Technologies for the Asia-Pacific Region. - 2003. - Vol. 3. - Pp. 1099-1103.

5. Gonzalez-Longatt F., Steliuk A., Hinojosa V.H. Flexible Automatic Generation Control System for Embedded HVDC Links // Proceedings of IEEE PowerTech conference. - Eindhoven, June 2015.

6. Gonzalez-Longatt, Francisco, Luis Rueda, Jose. PowerFactory Applications for Power System Analysis. Springer, 2015. $-489 \mathrm{p}$.

7. Hsu C.-T., Kang M.-S., Chen C.-S. Design of adaptive load shedding by artificial neural networks // IEE Proc. Gener. Transm. Distrib. - 2005. - Vol. 152. - No 3. - Pp. 415-421. 
8. Nanda J., Mishra S., Mishra P. and Sajith K. A novel classical controller for automatic generation control in thermal and hydrothermal system / Joint International Conference on Power Electronics, Drives and Energy Systems, India. - 2010. - Pp. 1-6.

9. Ramavathu S.N., Datla V.T., Pasagadi H. Islanding Scheme and Auto Load Shedding to Protect Power System // International Journal of Computer and Electrical Engineering. - 2013. - Vol. 1. - No 4. - Pp. 508-512.

10. Shahgholian G., Salary M.E. Effect of Load Shedding Strategy on Interconnected Power Systems Stability When a Blackout Occurs // International Journal of Computer and Electrical Engineering. - 2012. - Vol. 4. No 2. - Pp. 212-217.

11. Talaq J., Al-Basri F. Adaptive fuzzy gain scheduling for load frequency control // IEEE Trans. on Power Systems. - 1999. - Vol. 14. - No 1. - Pp. 145-150.

12. Technical Background for the Low Frequency Demand Disconnection Requirements. Available at: https://www.entsoe.eu/Documents/Network\%20codes\%20documents/NC\%20ER/141215 Technical backgrou nd for_LFDD.pdf. - 2014. - 20 p. (accessed 24.11.2016)

УДК 621.311:681.3

\section{МОДЕЛЮВАННЯ НОРМАЛЬНИХ ТА АВАРІЙНИХ РЕЖИМІВ ОБ'ЄДНАНОЇ ЕНЕГОСИСТЕМИ} УКРАЇНИ ДЛЯ ДОСЛІДЖЕННЯ СТІЙКОСТІ ЗА ЧАСТОТОЮ

О.В. Кириленко ${ }^{1}$, академік НАН України, В.В. Павловський ${ }^{1}$, докт.техн.наук, А.О. Стелюк ${ }^{1}$, канд.техн.наук, О.В. Леньга ${ }^{1}$, М.В. Вишневський ${ }^{2}$

1 - Інститут електродинаміки НАН України, пр. Перемоги, 56, Київ, 03057, Україна,

2 - Державне підприсмство «Національна енергетична компанія «Укренерго»,

вул. С. Петлюри, 25, Київ, 01032, Україна.

e-mail: astelyuk@gmail.com

Підключення об'єднаної енергетичної системи (ОЕС) Украӥни на паралельну роботу з енергооб'єднанням ENTSO-E потребує удосконалення протиаварійного керування та гармонізації вимог щзодо автоматичного регулювання частоти та потужності відповідно до тих, щуо діють в ENTSO-E. Для дослідження процесів зміни частоти та активної потужності необхідно розробити деталізовану модель, яка містить пристрої автоматичного частотного розвантаження, частотну автоматику енергоблоків атомних електростанцій, систему автоматичного регулювання частоти та потужності, а також магістральні мережі 750-220 кВ ОЕС Украйни. Досліджено стійкість за частотою иляхом моделювання електромеханічних перехідних прочесів 3 використанням програмного забезпечення DIg-SILENT PowerFactory. Наведено результати досліджень для виникнення різних збурень. Бібл. 12, рис. 5.

Ключові слова: стійкість за частотою, автоматичне частотне розвантаження, частотна автоматика, перетік потужності, первинне та вторинне регулювання, система автоматичного регулювання частоти та потужності, об'єднана енергосистема.

УДК 621.311:681.3

МОДЕЛИРОВАНИЕ НОРМАЛЬНЫХ И АВАРИЙНЫХ РЕЖИМОВ ОБЪЕДИНЕННОЙ ЭНЕРГОСИСТЕМЫ УКРАИНЫ ДЛЯ ИССЛЕДОВАНИЯ УСТОЙЧИВОСТИ ПО ЧАСТОТЕ

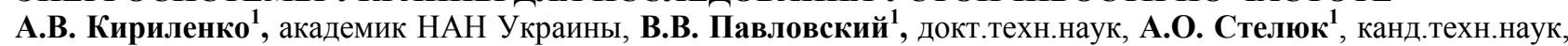
О.В. Леньга ${ }^{1}$, Н.В. Вишневский ${ }^{2}$

1 - Институт электродинамики НАН Украины, пр. Победы, 56, Киев, 03057, Украина,

2 - Государственное предприятие «Национальная энергетическая компания «Укрэнерго», ул. С. Петлюры, 25, Киев, 01032, Украина. e-mail: $\underline{\text { astelyuk@gmail.com }}$

Подключение объединённой энергетической системы (ОЭС) Украины на параллельную работу с энергообъединением ENTSO-E требует усовершенствования противоаварийного управления и гармонизации требований в части автоматического регулирования частоты и мощчности в соответствии с действующими в ENTSO-E. Для исследования процессов регулирования частоты и активной мощности необходимо разработать детализированную модель, учитывающую устройства автоматической частотной разгрузки, частотную автоматику энергоблоков атомных электростанций, систему автоматического регулирования частоты и мощности, а также магистральные сети 750-220 кВ ОЭС Украины. Исследована устойчивость по частоте путем моделирования электромеханических переходных прочессов с использованием программного обеспечения DIgSILENT PowerFactory. Приведены результаты исследований в случае возникновения различных возмущений. Библ. 12, рис. 5.

Ключевые слова: устойчивость по частоте, автоматическая частотная разгрузка, частотная автоматика, переток мощности, первичное и вторичное регулирование, система автоматического регулирования частоты и мощности, объединенная энергосистема. 